\title{
ステンレス基材上ヘのダイレクト高被覆極薄貴金属 無電解めっきを可能とする特殊表面改質技術
}

\author{
迎展彰 ${ }^{\mathrm{a}}$, 吉田 隆弘 ${ }^{\mathrm{a}}$ \\ a 東洋鋼釷侏) 技術研究所 ( T 744-8611 山口県下松市東豊井 1296-1)

\begin{abstract}
Specific Pretreatment Technology for Direct Electroless Precious Metals Plating on Stainless Substrates with Higher Ratio and Thinner Film Thickness
\end{abstract}

Nobuaki MUKAI a and Takahiro YOSHIDA ${ }^{\mathrm{a}}$

${ }^{a}$ R\&D Center, Toyo Kohan Co., Ltd.(1296-1, Higashitoyoi, Kudamatsu-shi, Yamaguchi 744-8611)

Keywords : Electroless Plating, Precious Metals, Stainless, Pretreatment, Conductivity, Corrosion Reistance

\section{1. はじめに}

$\mathrm{Au}$ を中心とした貴金属は耐食性, 導電性の観点で優れた 性能を有していることから, 従来, コネクター, スイッチ, もしくはプリント配線板などに使用されている。また, 2020 年の東京オリンピックに向けて水素社会の実現のために固体 高分子型燃料電池が再び脚光を浴びており, 電気会社や自動 車会社からこの燃料電池が市販されるような時代に変化して きている。特に固体高分子型燃料電池の内部材料には, 高導 電性だけでなく高耐酸性も必要であるため, 基材にはステン レスを用いることもあり，近年ではチタンも用いられている。 高導電性とともに高耐食性を確保するためには, 基材にカー ボンコーティングだけでなく, Au や Pt, Pd 等の貴金属をめっ きで成膜することも多いが， $\mathrm{Au}$ に関しては，新たな可能性 を見出す新しい $\mathrm{Au}$ めっき技術として硬質めっきの研究 ${ }^{1)}$ や, 高価な $\mathrm{Au}$ の薄膜化の研究 ${ }^{2), 3)}$ も盛んに行われている。一方, 基材となるステンレスについても, 耐食性を向上させるため に合金元素を添加する研究 ${ }^{4)}$ や酸化处理による研究 ${ }^{5)}$ も行わ れている。このようなステンレス表面に $\mathrm{Au}$ めっき層が形成 された $\mathrm{Au}$ 被覆ステンレス材においては, 通常, ステンレス 表面と $\mathrm{Au}$ めっき層の密着性を向上させるため, $\mathrm{Au}$ めっき 層を形成させる前にステンレス基材上に下地 $\mathrm{Ni}$ めっき層が

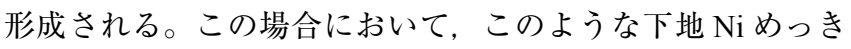
層上に $\mathrm{Au}$ めっき層を形成した際， $\mathrm{Au}$ めっき層にピンホー ルが多く発生すると, 腐食環境下においては下地 Ni めっき 層から Ni が溶出し, Au めっき層の剥離が発生するだけでな く, ガルバニック腐食により腐食が加速し, ステンレス基材 からも多量の金属が溶出する問題がある。一般的にピンホー ルを低減するためには $\mathrm{Au}$ めっき層を厚膜化させるが, 高価 な $\mathrm{Au}$ の省 $\mathrm{Au}$ 化のため, $\mathrm{Au}$ の厚みを薄くすると $\mathrm{Au}$ めっき 層の被覆率が著しく低下することにより, $\mathrm{Au}$ めっ層の密 着性が低下するとともに, 前述のようにステンレス基材から
の多量な金属が溶出するという不可避的な側面がある。さら に，貴金属をめっき液中でイオンとして保持するためにはシ アンが多く用いられているが，これらのめっき液は毒性が高 く，環境への影響が大きいという側面もある。 本研究は，これらの実状に鑑みてなされたものであり， $\mathrm{Au}$ を中心とした貴金属めっき層を薄膜化させた場合においても， 被覆率及び密着性を向上させることができ, これにより, 耐 食性に優れ，かつ導電性にも優れ，同時にコスト的に有利な 貴金属めっき被覆ステンレス材を主に固体高分子型燃料電池 分野に提供することが目的であり, また, 環境調和及び作業 環境の安全性の観点からノーシアン系浴を用いることを研究 指針とした。これらのめっき被覆ステンレス材を提供するた めには, ステンレス表面のめっき前処理工程における特殊改 質による特異的組成変質がキーテクノロジーであり, 本報で は, この特異的変質の発現条件, 化学構造の解析による $\mathrm{Au}$ めっきの析出機構と本めっき材料の性能について述べる。

\section{2. 実験方法}

\section{1 基材表面の特殊前処理と無電解貴金属めっき}

ステンレス基材は特に限定されないが，一般的に高い耐食 性を有する SUS316L 板 (厚み：0.1 mm)を用いた。SUS316L の表面をアセトンで洗浄した後, 一般的に類推される非酸化 性の単独の酸, あるいは混酸, A, B, 及び C を用いて, 濃度, 温度, 浸漬時間を変化させ, SUS316L の表面改質を行った。 各表面改質後, 水洗を行い, 置換型無電解 $\mathrm{Au}$ めっき処理を 行った。置換型ノーシアン系無電解 $\mathrm{Au}$ めっき液には奥野製 薬工業株式会社製フラッシュゴールド NCを用い, めっき温 度を $70{ }^{\circ} \mathrm{C}$ と, 5 分間めっきを行った。また, 他貴金属のノー シアン系の無電解めっき処理の試みも行い, Pd めっき液に は奥野製薬工業株式会社製パラトップを用い，めっき温度を

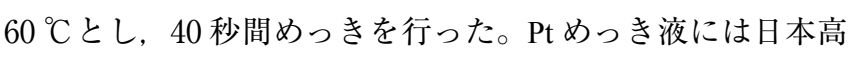
純度化学株式会社製 IM-Pt を用い, めっき温度を $55^{\circ} \mathrm{C}$ とし, 
3 分間めっきを行った。各貴金属の析出有無の評価は蛍光 X 線分析装置 (Rigaku 社製 ZSX-100e)により行い，析出金属が 検出された場合を○，検出されなかった場合を×とした。ま た，密着性の評価は，粘着テープ(ニチバン製ナイスタック 強力タイプ）ぬめき表面に貼り付け, テープを剥離させ, テープへのめっき膜残りを観察することにより行い，剥離が 無かった場合を $\bigcirc$, 一部剥離した場合を $\triangle$, 全面剥離した場 合を $\times$ ，めっき膜が形成されず評価不能であった場合を N.D. とした。めっき厚みの評価は, めっき材を $4 \mathrm{~cm}^{2}$ に切り 出し, めっき皮膜を王水 $6 \mathrm{ml}$ に溶解させた後, 純水を加え て $100 \mathrm{ml}$ に調整した溶解液中の貴金属量を ICP-AES（島津製 作所社製 ICPE-9000) で測定し，その質量をめっき厚みに換 算した。めっき被覆率の評価は, めっき表面を走査型電子顕 微鏡 SEM（日立八イテクノロジー社製 S-4800）にて観察し, SEM 写真を明度閾值で 2 元化することで画像処理した後, めっき層が形成された面積の割合を測定することにより行っ た。

\section{2 めっき材の性能評価}

\section{2.1 耐食性}

$\mathrm{Au}$ めっき層が形成されためっき材について, 縦 $35 \mathrm{~mm}$, 横 $20 \mathrm{~mm}$ の面積が露出するようにポリイミドテープでマス キングし, $\mathrm{pH}=1.0$, 温度 $90{ }^{\circ} \mathrm{C}$ の硫酸水溶液に 100 時間浸 漬した後, めっき材を取り出し, 硫酸水溶液中に溶出した金 属イオン $(\mathrm{Fe}, \mathrm{Cr}, \mathrm{Mo}, \mathrm{Ni})$ の質量濃度 $(\mathrm{g} / \mathrm{L})$ を ICP-AES（島 津製作所社製 ICPE-9000)で測定することにより行った。なお, 比較には，めっきを行っていない無垢の SUS316L を用いた。

2. 2.2 導電性

$\mathrm{Au}$ めっき層が形成されためっき材について，接触抵抗の 測定を行った。接触抵抗の測定は, 固体高分子型燃料電池で 一般的に行われている測定方法とした。まず，めっき材を縦 $20 \mathrm{~mm} \times$ 横 $20 \mathrm{~mm}$ にカットし, めっき材の表面及び裏面に カーボンクロス(東レ社製 TGP-H-090)を介して, 銅製の電極 をサンドイッチし, 固定した。次いで, 銅電極にテンシロン により一定の荷重を加えながら, 抵抗計(日置電機社製ミリ オームハイテスタハイテスタ 3504)を用いて, めっき材をサ ンドイッチした上下のカーボンクロス間の抵抗を測定した。 なお，比較には，めっきを行っていない無垢の SUS316L を 用いた。

\section{3 SUS316L 基材の表面状態の解析}

酸による SUS316L 表面の改質後の表面状態を組成変化に 対して, 走査型オージェ電子分光分析装置 (JEOL 社製 JAMP-9500F), 化学結合変化に対して, X 線光電子分光装置 (アルバックファイ社製 Versa Probe II)，断面変化に対して, 透過型電子顕微鏡 (日立八イテクノロジー社製 HF-2700), 化 学構造変化に対して, 透過型電子顕微鏡(日立ハイテクノロ ジー社製 HF-2000)を用いた。

\section{3. 実験結果}

\section{1 表面改質とめっき性及び密着性の関係}

表 1 に表面改質条件とめっき性及び密着性の調査結果を示 す。酸 $\mathrm{B}$ 及び $\mathrm{C}$ で表面改質を行った場合は，いずれの条件 下に打いても, めっきが全く進行しなかった。一方, 酸 $\mathrm{A}$
で表面改質を行った場合において, 特定の条件下では, めっ き性も良好, かつ密着性も良好な $\mathrm{Au}$ めっき膜が得られるこ とがわかった。この酸 $\mathrm{A} の$, 濃度, 温度, 浸漬時間の相関

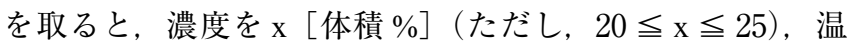
度を $\mathrm{y}\left[{ }^{\circ} \mathrm{C}\right]$, 浸漬時間を $\mathrm{z}$ [秒］とした場合, 前述のように めっき性, 密着性を満たす相関式は,

$$
0.6 \times 10^{6} \leqq \mathrm{x}^{2} \cdot(\mathrm{y}-40)^{2} \cdot \sqrt{\mathrm{z}} \leqq 3.0 \times 10^{6}
$$

であることがわかった。すなわち，酸 Aにより，この相関 式を満たす表面改質を行えば，SUS316L 基材上に下地層を 挿入せず，ダイレクトにめっき性，密着性が良好な $\mathrm{Au}$ めっ きが可能となる。また，この相関式を満たす条件下で SUS316L 基材表面を改質すれば，他貴金属として無電解 Pd めっき, 無電解 Pt めっきも同様の現象が発現することも見 出された。

図 1 にSUS316L 基材上にダイレクトに無電解めっきした $\mathrm{Au}$ めっき膜, $\mathrm{Pd}$ めっき膜, 及び $\mathrm{Pt}$ めっき膜の表面の SEM 画像を示す。各めっき膜のめっき厚みは, ICP-AES による分 析から，各々 $3 \mathrm{~nm}, 10 \mathrm{~nm}, 20 \mathrm{~nm}$ であった。これらのめっ き膜の被覆率を算出すると, 極めて薄いめっき膜にも関わら ず， $\mathrm{Au}$ めっき膜では $98.2 \%, \mathrm{Pd}$ 及び Pt めっき膜では $100 \%$ であった。

表 1 表面改質条件とめっき性及び密着性

\begin{tabular}{|c|c|c|c|c|c|}
\hline \multirow{2}{*}{ 酸種 } & \multirow{2}{*}{$\begin{array}{c}\text { 濃度 } \\
\text { (体積\%) }\end{array}$} & \multirow{2}{*}{ 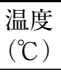 } & \multirow{2}{*}{$\begin{array}{c}\text { 浸漬時間 } \\
\text { (秒) }\end{array}$} & \multicolumn{2}{|c|}{ めっき層 } \\
\hline & & & & めっき性 & 密着性 \\
\hline \multirow{22}{*}{ A } & \multirow{8}{*}{25} & \multirow{4}{*}{70} & 5 & 0 & 0 \\
\hline & & & 10 & 0 & O \\
\hline & & & 15 & 0 & 0 \\
\hline & & & 20 & 0 & $\bigcirc$ \\
\hline & & 60 & 120 & 0 & 0 \\
\hline & & \multirow{3}{*}{50} & 180 & 0 & 0 \\
\hline & & & 300 & 0 & 0 \\
\hline & & & 600 & 0 & 0 \\
\hline & \multirow{5}{*}{20} & \multirow{3}{*}{70} & 20 & 0 & 0 \\
\hline & & & 40 & 0 & 0 \\
\hline & & & 60 & 0 & 0 \\
\hline & & 60 & 60 & 0 & 0 \\
\hline & & 50 & 300 & 0 & $\triangle$ \\
\hline & \multirow{3}{*}{25} & \multirow{9}{*}{70} & 30 & 0 & $x$ \\
\hline & & & 60 & 0 & $x$ \\
\hline & & & 300 & 0 & N.D. \\
\hline & \multirow{3}{*}{5} & & 30 & $x$ & N.D. \\
\hline & & & 60 & $\times$ & N.D. \\
\hline & & & 300 & $x$ & N.D. \\
\hline & \multirow{3}{*}{10} & & 30 & $\times$ & N.D. \\
\hline & & & 60 & $x$ & N.D. \\
\hline & & & 300 & $\times$ & N.D. \\
\hline \multirow{11}{*}{ B } & \multirow{3}{*}{5} & \multirow{11}{*}{60} & 30 & $x$ & N.D. \\
\hline & & & 60 & $x$ & N.D. \\
\hline & & & 300 & $\times$ & N.D. \\
\hline & & & 30 & $x$ & N.D. \\
\hline & 10 & & 60 & $\times$ & N.D. \\
\hline & & & 300 & $x$ & N.D. \\
\hline & \multirow{5}{*}{25} & & 10 & $x$ & N.D. \\
\hline & & & 30 & $x$ & N.D. \\
\hline & & & 60 & $x$ & N.D. \\
\hline & & & 120 & $x$ & N.D. \\
\hline & & & 300 & $x$ & N.D. \\
\hline \multirow{3}{*}{$\mathrm{C}$} & \multirow{3}{*}{10} & \multirow{3}{*}{70} & 30 & $x$ & N.D. \\
\hline & & & 60 & $x$ & N.D. \\
\hline & & & 300 & $x$ & N.D. \\
\hline \multicolumn{4}{|c|}{ 表面改質無し } & $x$ & N.D. \\
\hline
\end{tabular}



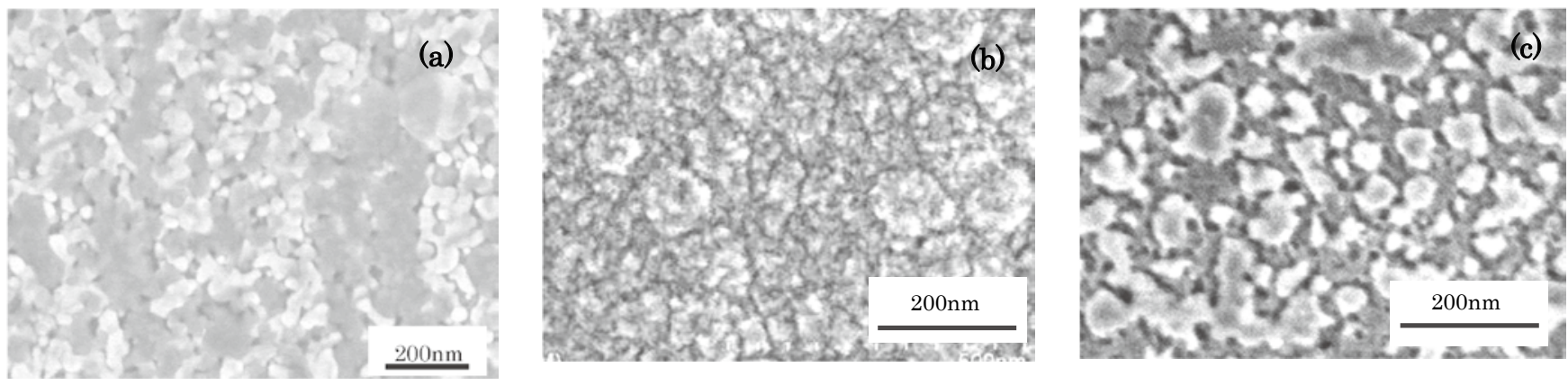

図 $1 \mathrm{Au}$ めっき膜表面 (a), Pd めっき膜 (b), Pt めっき膜 (c) の SEM 像

\section{2 めっき膜の性能}

図 2 に $\mathrm{Au}$ めっき材の性能として, 耐食性及び接触抵抗を 示す。耐食性については，無垢の SUS316L 基材が Fe, Cr, Mo, Ni の総溶出量が 38 ppm であるのに対して, Au めっき 材ではピンホール起因のガルバニック腐食が進行することが 無く, 総溶出量は $3 \mathrm{ppm}$ であり, 無垢の SUS316L よりも高 耐食性となることがわかった。また，固体高分子型燃料電池 の内部材料において重要な性能である接触抵抗についても, 荷重によらず, SUS316L 基材よりも著しく低いことがわかっ た。これらの結果は被覆率が如何に高いかを裏付ける結果と も言える。

\section{3 SUS316L の表面状態の解析}

図 3 にSUS316L 表面の改質後表面の AES により検出され た $\mathrm{Cr} / \mathrm{O}$ 強度比，及び $\mathrm{Cr} / \mathrm{Fe}$ 強度比をプロットした結果を示す。 表 1 に示しためっき性及び密着性が良好となる条件と各強度 比を照合すると, $\mathrm{Cr} / \mathrm{O}=0.05 \sim 0.20, \mathrm{Cr} / \mathrm{Fe}=0.50 \sim 0.80$
となる表面組成の場合においてのみ，めっき性及び密着性が 良好なめっきが可能となることがわかった。さらに，図４に （式 1）を満たす酸 $\mathrm{A}$ の濃度 25 体積 $\%$, 温度 $70{ }^{\circ} \mathrm{C}$, 浸漬時 間 10 秒と (式 1)を満たさない浸漬時間 60 秒及び表面改質無 しの SUS316 基材表面の $\mathrm{Fe} 2 \mathrm{p}$ 軌道, $\mathrm{Ni} 2 \mathrm{p}$ 軌道, 及び $\mathrm{Cr} 2 \mathrm{p}$ 軌道の XPS による化学結合変化を示す。（式 1)を満たす表 面には, Fe 2p 軌道において $707 \mathrm{eV}$ 付近に Fe (metal) ピーク が強く発現しており, なおかつ, Ni $2 \mathrm{p}$ 軌道において $853 \mathrm{eV}$ 付近に Ni (metal) ピークが強く発現した。一方，浸漬時間 60 秒及び表面改質無しの表面には，このような強い Fe (metal), $\mathrm{Ni}$ (metal)のピークは無く, また，浸漬時間 60 秒に限っては, $857 \mathrm{eV}$ 付近に $\mathrm{Ni}$ の酸化物形成を示唆する $\mathrm{Ni}-\mathrm{O}$ のピークが 顕著に発現した。また, 図 5 に(式 1)を満たす酸 A の濃度 25 体積 \%, 温度 $70{ }^{\circ} \mathrm{C}$, 浸漬時間 10 秒と (式 1 )を満たさな い浸漬時間 60 秒及び表面改質無しの SUS316L 基材表面の断 面 TEM写真及び電子線回折パターンを示す。未処理の
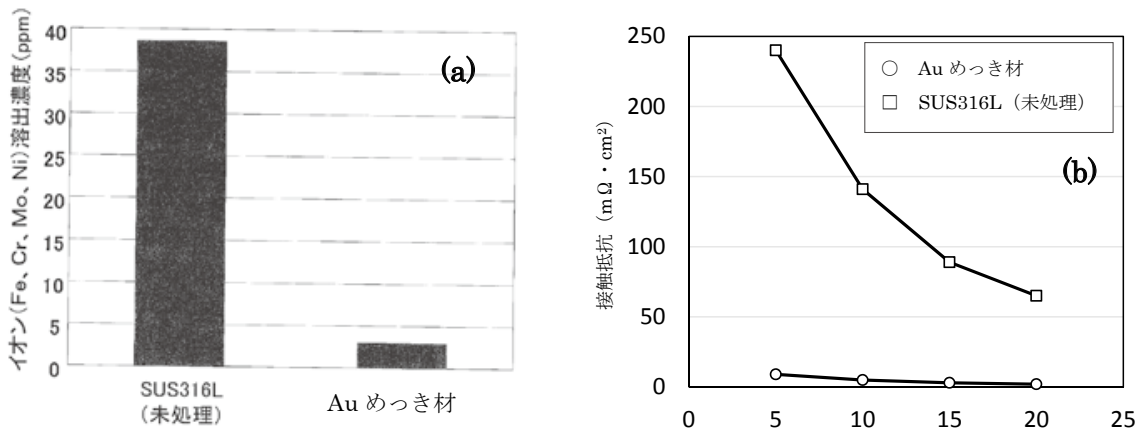

図 $2 \mathrm{Au}$ めっき材の耐食性 (a) 及び接触抵抗 (b)

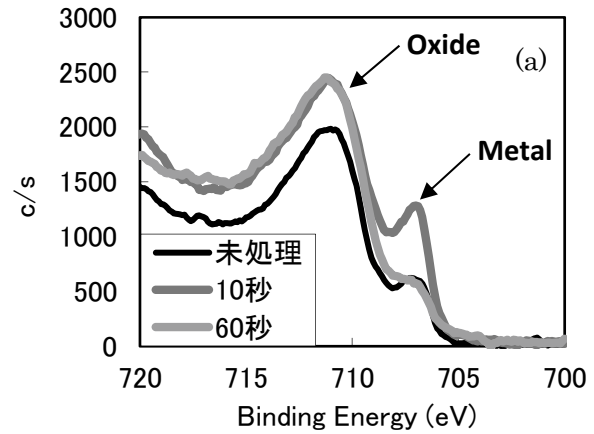

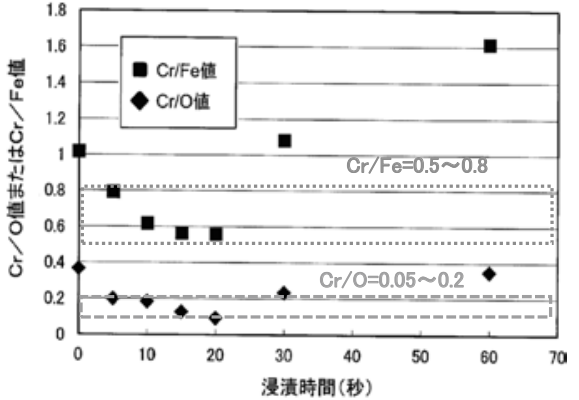

図 3 酸洗浸漬時間による $\mathrm{Cr} / \mathrm{Fe}$ 及び $\mathrm{Cr} / \mathrm{O}$ の AES 強度比

図 4 酸洗処理時間による Fe $2 p(a), N i 2 p(b)$ 及び Cr $2 p(c)$ の XPS ピークシフト 


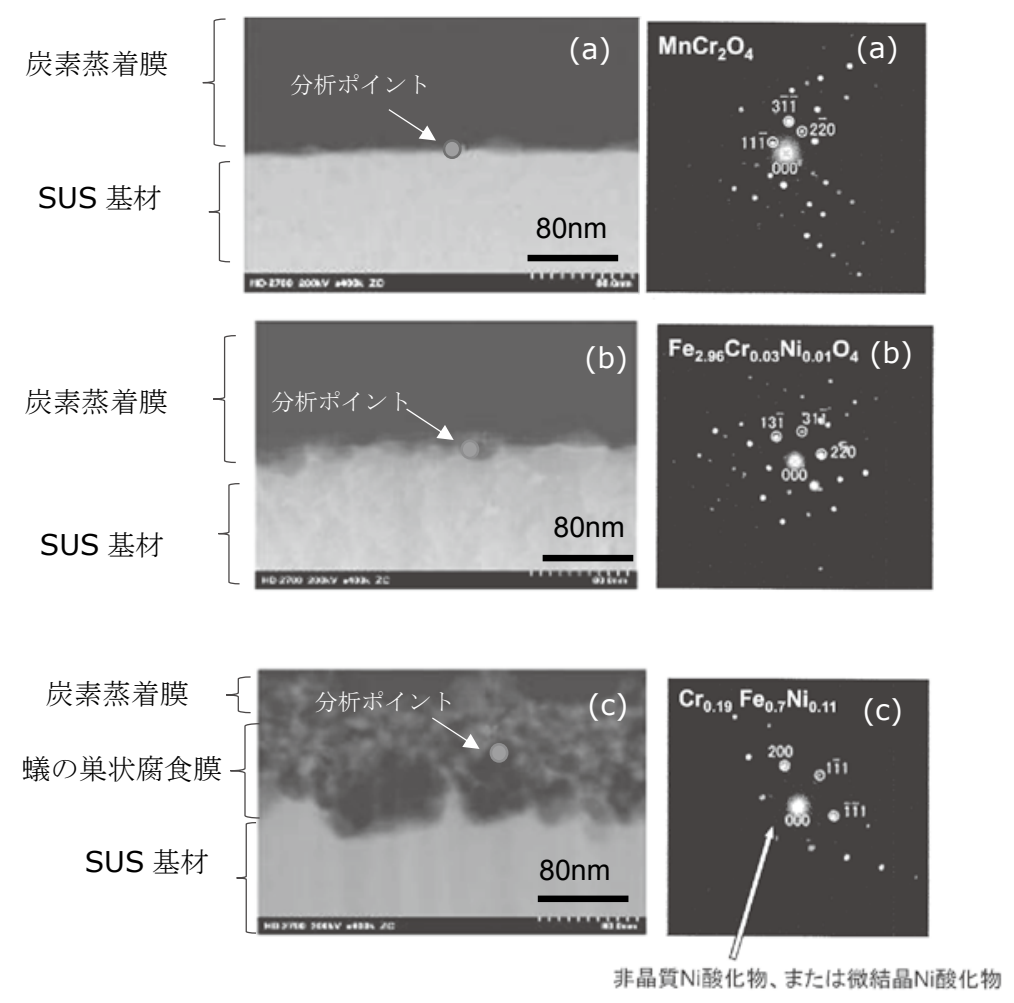

図 5 特殊酸洗前後の SUS316L 表層の断面 TEM 像及び回折パターン 未処理 $(\mathrm{a}), 10$ 秒処理後 $(\mathrm{b}), 60$ 秒処理後 (c)

SUS316L 表面は平滑であり, $\mathrm{Cr}$ を主成分とした $\mathrm{MnCr}_{2} \mathrm{O}_{4}$ の 酸化膜が存在していた。また，(式 1 )を満たす浸漬時間 10 秒後ではXPS の結果と類似し, Fe を主成分とした酸化膜に 変質し, かつ, 表面がやや荒れていることがわかった。一方, 浸漬時間 60 秒後では, これもXPS の結果と類似して, 非晶 質の $\mathrm{Ni}$ 酸化物あるいは微結晶の $\mathrm{Ni}$ 酸化物に変質するととも に, その層が約 $100 \mathrm{~nm}$ 程度の蟻の巣状の層となっているこ とがわかった。なお, Cr $2 \mathrm{p}$ 軌道については, 大きな変化は 確認できなかった。

\section{4. 考察}

SUS316L 基材表面に，めっき厚が極めて薄いにも関わらず, 被覆率が高く, かつ, 密着性が良好となるめっきが可能とな る成長機構は, 後述のように考えられる。（式 1)を満たさな い表面改質が無い条件下では, SUS316L 基材表面の極表層 の $\mathrm{Cr}$ 酸化物が不活性なため, めっき反応が起こらない。また, 酸 Aの（式 1)を満たす条件下では, SUS316L 基材表面の $\mathrm{Cr}$ 酸化物が一部除去されると同時に, 活性な金属結合状態を有 する $\mathrm{Fe}$ 基, $\mathrm{Ni}$ 基が濃化した層が表層に発現することにより， 置換めっき反応の駆動力となる下地溶解が容易に進行し, 高 密度なサイトにて置換めっきが終了する。そのため, 結果的 に, めっきが容易に進行するとともに, 膜厚が極めて薄い領 域においても被覆率の高いめっきが可能となると考えられる。 一方，（式 1）を満たさない表面改質条件下では, SUS316L 基 材表層が脆弱な Ni 酸化物を主体とした層を形成しており, 蟻の巣状腐食を発生させていることからもわかるように, めっきは可能であるが, 基材表面と $\mathrm{Ni}$ 酸化物層の密着が悪 いため, 結果的に密着の悪いめっきとなると考えられる。

\section{5.おわりに}

特殊な表面改質により, 一般的にダイレクト無電解めっき が困難な SUS316L 基材上へのめっきが可能となるが, これは, 特定の表面改質条件下で SUS316L 基材表面そのものの特異 的な変質を適正にコントロールすることにより発現するもの と考えられる。したがって, 極めて薄いめっき厚においても 高被覆率を有する貴金属無電解めっきには, この前処理とし ての特殊な表面改質が必須であることがわかった。

したがって，このような表面改質技術の適用により， SUS316L 基材に高価な貴金属を最小限の使用量で薄めっき をすることができ，低接触抵抗化や高耐食性をも付与できる めっき材料を提供できると考える。さらに本報での特殊表面 改質を深化させた表面処理により，一般的に SUS316Lより もさらに高耐食性を有する純チタンよりも高耐食性を有する めっき材料が得られるようにもなってきているため, 表面の 変質に拘った本表面処理技術の今後の様々な分野への用途展 開が期待できる。

(Received September 18, 2015)

\section{文献}

1 ）岩田良太, 千田一敬; THE CHEMICAL TIMES, 212, (2), 13 (2009).

2 ) 中村俊博, 山本貴代, 永山富男, 縄舟秀美; 京都市産業技術研究所 研究報告, No.2 (2012).

3 ) 加藤 勝; THE CHEMICAL TIMES, 189, (3), 10 (2003).

4 ) 梶村治彦; Journal of Society of Materials Science, Japan, 9, 862 (2011). 